\title{
The Toll-like receptors mRNA expression profile in the pineal gland of sheep during long and short days
}

\author{
J. Bochenek ${ }^{1}$, J. Skipor ${ }^{2}$, M. Kowalewska² and A.P. Herman ${ }^{1,3}$ \\ ${ }^{1}$ The Kielanowski Institute of Animal Physiology and Nutrition, Polish Academy of Sciences, 05-110 Jabłonna, Poland \\ ${ }^{2}$ Institute of Animal Reproduction and Food Research, Polish Academy of Sciences, Tuwima 10, 10-748 Olsztyn, Poland
}

KEY WORDS: pineal gland, Toll-like receptors, photoperiod, melatonin, ewe

Received: $\quad 12$ June 2015

Revised: $\quad 31$ August 2015

Accepted: 9 September 2015

${ }^{3}$ Corresponding author:

e-mail: a.herman@ifzz.pan.pl
ABSTRACT. Interaction between the immune system and pineal gland seems to be bidirectional. The feedback effect of an inflammatory response on the pineal gland is poorly understood, however. This study was performed to analyse the pattern of mRNA expression of receptors belonging to the Toll-like receptors (TLR) family in the pineal gland of ewes under different photoperiod conditions. TLRs are involved in the initiation of the innate immune response because they recognize different pathogen-associated molecular patterns (PAMPs). The experiment was carried out on adult Blackface ewes during long-day (LD, 18:6, June; $n=6)$ and short-day (SD, 6:18, December; $n=6$ ) periods. The animals were euthanized $5 \mathrm{~h}$ after sunset (at 21:00 during SD and 2:00 during LD). The mean concentration of circulating melatonin in the last hour of the experiment was higher $(P<0.05)$ during the SD $\left(270 \pm 15 \mathrm{pg} \cdot \mathrm{ml}^{-1}\right)$ compared with the LD period $\left(108 \pm 5 \mathrm{pg} \cdot \mathrm{ml}^{-1}\right)$. The expression of genes encoding each TLR was differentiated. TLR3 had the highest mRNA expression, followed by TLRs 1, $2,5,7,9,8,4,10$ and 6 . Gene expression also varied for each TLR and was influenced by the photoperiod and/or melatonin. The gene whose expression varied the most was TLR10 (coefficient of variation, $42 \%$ ) during the LD period, but during the SD period, the expression of TLR6 varied most (coefficient of variation, $42 \%$ ). The study showed that the cells of the pineal gland express transcripts for all ten members of the TLR family, therefore, the functioning of this gland may be affected by number of PAMPs recognized by these receptors.

\section{Introduction}

In the vertebrate, the pineal gland is a neuroendocrine organ converting environmental photoperiodic information into a biochemical messenger - melatonin. This molecule regulates the activity of numerous target tissues after its release into the bloodstream and cerebrospinal fluid (Skinner and Malpaux, 1999). The pineal gland has evolved from the roof of the forebrain in the main part of the epithalamus, and is formed by three types of cells: pinealocytes, glia cells and neurons. In non-mammal vertebrates, the pinealocytes are photoreceptors and react directly to light, while in mammals, they are not directly sensitive to light (Markus and Ferreira, 2011). A phylogenetically conserved feature is increased melatonin synthesis during darkness. The magnitude and duration of the nocturnal increase in melatonin synthesis is dependent on the length of the dark phase of the photoperiodic cycle. Melatonin synthesis acts as a 'clock' and 'calendar' for 
other biological activities. It occurs in all vertebrate species, regardless of their diurnal or nocturnal locomotor activity, and it is thus a message of darkness and not of the rest or sleep period (Skwarlo-Sonta et al., 2003). It is noteworthy that melatonin secretion from the pinealocytes is controlled by the suprachiasmatic nucleus (SCN) in the anterior hypothalamus, which receives light/dark signals via the retinohypothalamic pathway (Moore, 1997). The rhythm generated by the $\mathrm{SCN}$ is then transmitted via the paraventricular nucleus (PVN), hindbrain, spinal cord, superior cervical ganglion (SCG) to pineal noradrenergic (NA) receptors (Arendt, 1998). In mammals, spontaneous bioelectrical and metabolic activity of the SCN neurons is highest during the day (or during the light phase of the circadian cycle). In the same phase, the impulsation of sympathetic neurons connecting the superior cervical ganglion with the pineal gland is negligible. At night, when the activity of the SCN neurons is decreased, there is an increase in the electrophysiological activity of sympathetic postganglionic fibres resulting in the release of NA from the nerve terminals (Gupta et al., 2005). Acting via $\beta 1$ - and $\alpha 1$-adrenergic membrane receptors, NA induces the synthesis of melatonin in the pinealocytes (Schomerus and Korf, 2005).

It is well established that among its numerous roles, melatonin acts as an immunomodulator, regulating the development, differentiation and function of lymphoid tissues. Moreover, diurnal and seasonal changes in immune function are thought to directly reflect changes in pineal melatonin production, which suggests an important role of circulating melatonin in the development and maintenance of immune function (Skwarlo-Sonta et al., 2003). The influence of melatonin on inflammatory and immune processes is ambiguous because it may act as both an activator and inhibitor of these responses (Carrillo-Vico et al., 2013). In the early phase of inflammation, melatonin enhances the inflammatory response, activating the production of inflammatory mediators such as phospholipase A2 (PLA2), 5-lipoxygenase (LOX), interleukin (IL)-1 and tumor necrosis factor- $\alpha$ (TNF- $\alpha$ ) (Radogna et al., 2010). On the other hand, melatonin contributes to the attenuation of chronic inflammation, down-regulating the production of PLA2, LOX, IL-1 and TNF- $\alpha$. Melatonin also induces the survival pathway in leukocytes and, due to its antioxidant properties, reduces oxidative stress in inflamed tissues (Radogna et al., 2010).

The interaction between the immune system and pineal gland seems to be bidirectional. The feedback effect of the inflammatory response on pineal gland neuroendocrine functions is poorly understood, however. Cytokines and other immune factors may possibly regulate pineal function indirectly, acting at the level of the SCN. It was found that inflammatory mediators such as cytokines, prostaglandins and histamine penetrate this region of the brain during an immune/inflammatory challenge (Fabris, 1994) and a study carried out on rodents showed high densities of cytokine receptors in the hypothalamus (Vitkovic et al., 2000). Even so, immune mediators and antigens may also directly affect the secretory activity of the pineal gland because it is a part of the brain lacking the blood-brain barrier and all molecules present in the blood can easily access this tissue. A few studies have shown that the secretory activity of pinealocytes could be modified by antigenic stimulation (Markowska et al., 2000), histamine (Zawilska et al., 1997), cytokines (Mucha et al., 1994) and prostaglandins (Voisin et al., 1993). Nonetheless, the spectrum of molecules affecting the pineal gland activity may be much broader.

In the present study we analysed the pattern of mRNA expression of receptors belonging to the Tolllike receptor (TLR) family. Mammalian TLRs comprise a large family consisting of at least 13 members, all of which have been identified in mice (Takeda and Akira, 2005), but only 10 members of this family have been found in sheep (Chang et al., 2009). TLRs play an important role in the initiation of the innate immune response because they are responsible for the recognition of different pathogen-associated molecular patterns (PAMPs). Recognition of microbial components by TLRs initiates signal transduction pathways that trigger gene expression. These gene products control innate immune responses and further instruct development of antigen-specific acquired immunity (Takeda and Akira, 2005). Determining the expression of TLR mRNAs in the pineal gland will shed new light on pineal-immune interaction.

This study was designed to verify the hypothesis that mRNAs encoding all of the receptors belonging to the TLR family identified in sheep to date are expressed in the pineal gland of sheep and that the transcription of these receptors may be influenced by the photoperiod and/or circulating melatonin.

\section{Material and methods}

\section{Animals and experimental design}

This study was performed on two groups of adult, two-year-old Blackface ewes during long-day (LD) $(16: 8$, June; $\mathrm{n}=6)$ and short-day (SD) $(8: 16$, December; $n=6)$ periods. The animals were maintained indoors in individual pens and were exposed 
to the natural daylight present at $52^{\circ} \mathrm{N}$ latitude and $21^{\circ} \mathrm{E}$ longitude. The ewes were in good condition, i.e. their body condition was estimated to be 3 on a five-point scale (Russel, 1991). The animals were acclimated to the experimental conditions for one month. The ewes were always within visual contact with other members of the flock to prevent isolation stress. The animals were fed a constant diet of commercial concentrates with hay and water available ad libitum, according to the recommendations proposed by the National Research Institute of Animal Production for adult ewes (IZ PIB-INRA, 2009). The experimental procedures were performed during the night, in the darkness under red light. One hour prior to euthanasia, four blood samples $(8 \mathrm{ml})$ were collected in 15-min intervals through a catheter implanted into the jugular vein the day prior to the experiment. After centrifugation in heparinized tubes, plasma was stored at $-20^{\circ} \mathrm{C}$ until assayed. The animals were euthanized $5 \mathrm{~h}$ after sunset at 21:00 during SD and 2:00 during LD. The brain was immediately removed from the skulls, and the pineal gland was dissected and immediately frozen in liquid nitrogen and stored at $-80^{\circ} \mathrm{C}$ until assay.

All procedures were performed with the consent of the Local Ethics Committee for Animal Experimentation of the Warsaw University of Life Sciences - SGGW.

\section{Assays}

Melatonin. Melatonin was assayed in the experimental media according to the method of Fraser et al. (1983) modified in the laboratory of the Kielanowski Institute of Animal Physiology and $\mathrm{Nu}-$ trition, using ovine anti-melatonin serum $(\mathrm{AB} / \mathrm{S} / 01$, Stockgrand Ltd., Surrey, UK). Synthetic melatonin (Sigma-Aldrich Co., St. Louis, MO, USA) was used as a standard and [O-methyl-3H]-melatonin (Amersham PLC, Amersham, UK) as a tracer. The sensitivity of the assay was $16.8 \pm 8.0 \mathrm{pg} \cdot \mathrm{ml}^{-1}$ and the intra- and inter-assay coefficients of variation were $10.5 \%$ and $13.2 \%$, respectively.

Isolation of mRNA from the pineal gland. Total RNA from the pineal fragments was isolated using the NucleoSpin ${ }^{\circledR}$ RNA/Protein Kit (MACHEREY-NAGEL Gmbh \& Co., Düren, Germany). All steps of the isolation were performed according to the manufacturer's protocol. The purity and concentration of the isolated RNA was quantified spectrophotometrically. RNA integrity was confirmed by electrophoresis using $1 \%$ agarose gel stained with ethidium bromide.
Real-Time PCR. To synthesize cDNA, the Maxima $^{\mathrm{TM}}$ First Strand cDNA Synthesis Kit for RT-qPCR (Thermo Fisher Scientific, Waltham, MA, USA) and $2 \mu \mathrm{g}$ of total RNA were used. Real-Time RT-PCR was performed using the HOT FIREPol EvaGreen ${ }^{\circledR}$ qPCR Mix Plus (Solis BioDyne, Tartu, Estonia) and HPLC-grade oligonucleotide primers (Genomed, Warszawa, Poland). Specific primer pairs for all of the analysed genes were used according to the literature (Table 1). One reaction mixture (total volume: $20 \mu \mathrm{l}$ ) contained: $4 \mu \mathrm{l}$ of PCR Master Mix (5×), $14 \mu \mathrm{l}$ of RNase-free water, $1 \mu \mathrm{l}$ of primers $(0.5 \mu 1$ each primer, working concentration $0.25 \mu \mathrm{M})$ and $1 \mu \mathrm{l}$ of the cDNA template. The reactions were run on a Rotor-Gene 6000 instrument (Qiagen, Düsseldorf, Germany). The following protocol was used: $95^{\circ} \mathrm{C}$ for $15 \mathrm{~min}$ and 30 cycles of $95^{\circ} \mathrm{C}$ for $10 \mathrm{~s}$ for denaturation, the temperature of annealing was dependent on the primers used for reaction (Table 1), but in all cases the hold time of this step was $20 \mathrm{~s}$, and $72^{\circ} \mathrm{C}$ for $10 \mathrm{~s}$ for extension. A final melting curve analysis was performed to confirm the specificity of the amplification.

Relative gene expression was calculated using the comparative quantification option (Rasmussen, 2001) of Rotor Gene 6000 software 1.7. (Qiagen, Düsseldorf, Germany). Three housekeeping genes were examined: glyceraldehyde-3-phosphate dehydrogenase $(G A P D H), \beta$-actin $(A C T B)$ and histone deacetylase 1 ( $H D A C 1)$. For normalization of the expression of TLR genes, the mean expression of these three housekeeping genes was used. The results are presented in arbitrary units as the ratio of the target gene expression to the mean expression of the housekeeping genes.

\section{Statistical analysis}

The concentration of melatonin is presented as the mean \pm SEM. Real-time RT-PCR results are presented as the relative gene expression (mean \pm SEM) of the TLR genes vs the mean expression of reference genes (GAPDH, ACTB and $H D A C 1$ ). All analyses were performed using GraphPad PRISM 6 (La Jolla, CA, USA), including calculations of the coefficient of variation for the expression values of each TLR gene, $t$-test for analysis of melatonin concentration during SD and LD, and, after $\log$ transformation, two-way analysis of variance (ANOVA) with multiple comparison Tukey's post-hoc test for analysis of expression of TLR genes in the pineal gland harvested during LD and SD. 
Table 1. Sequences of oligonucleotide primers used for Real-Time PCR assay

\begin{tabular}{|c|c|c|c|c|c|c|}
\hline $\begin{array}{l}\text { GenBank } \\
\text { Acc. No. }\end{array}$ & Gene & $\begin{array}{l}\text { Amplicon } \\
\text { size (bp) }\end{array}$ & $\begin{array}{l}\text { Temperature } \\
\text { of primers } \\
\text { annealing }\end{array}$ & $\begin{array}{l}\text { Forward/ } \\
\text { reverse }\end{array}$ & $\begin{array}{l}\text { Sequence } \\
5^{\prime} \rightarrow 3^{\prime}\end{array}$ & Reference \\
\hline AY957612 & TLR1 & 208 & $58^{\circ} \mathrm{C}$ & $\begin{array}{l}\text { forward } \\
\text { reverse }\end{array}$ & $\begin{array}{l}\text { CCCACAGGAAAGAAATTCCA } \\
\text { GGAGGATCGTGATGAAGGAA }\end{array}$ & Menzies and Ingham, 2006 \\
\hline AM981300 & TLR2 & 159 & $58^{\circ} \mathrm{C}$ & $\begin{array}{l}\text { forward } \\
\text { reverse }\end{array}$ & $\begin{array}{l}\text { GGCTGTAATCAGCGTGTTCA } \\
\text { GATCTCGTTGTCGGACAGGT }\end{array}$ & Chang et al., 2009 \\
\hline AM981301 & TLR3 & 150 & $60^{\circ} \mathrm{C}$ & $\begin{array}{l}\text { forward } \\
\text { reverse }\end{array}$ & $\begin{array}{l}\text { TCAGCTCCAACTGGAGAACC } \\
\text { CACCCAGGAGAGAACTCTTTGA }\end{array}$ & Chang et al., 2009 \\
\hline AY957615 & TLR4 & 117 & $58^{\circ} \mathrm{C}$ & $\begin{array}{l}\text { forward } \\
\text { reverse }\end{array}$ & $\begin{array}{l}\text { GGTTCCCAGAACTGCAAGTG } \\
\text { GGATAGGGTTTCCCGTCAGT }\end{array}$ & Herman et al., 2013 \\
\hline AM981303 & TLR5 & 152 & $58^{\circ} \mathrm{C}$ & $\begin{array}{l}\text { forward } \\
\text { reverse }\end{array}$ & $\begin{array}{l}\text { CGACAACCTCCAAGTTCTCAA } \\
\text { TTTCCCCAGGAATTTGAATG }\end{array}$ & Chang et al., 2009 \\
\hline AM981304 & TLR6 & 213 & $58^{\circ} \mathrm{C}$ & $\begin{array}{l}\text { forward } \\
\text { reverse }\end{array}$ & $\begin{array}{l}\text { TTTGTCCTCAGGAACCAAGC } \\
\text { TCATATTCCAAAGAATTCCAGCTA }\end{array}$ & Chang et al., 2009 \\
\hline AM981305 & TLR7 & 153 & $60^{\circ} \mathrm{C}$ & $\begin{array}{l}\text { forward } \\
\text { reverse }\end{array}$ & $\begin{array}{l}\text { CTGGACCATCTGGTGGAGAT } \\
\text { GCTGGTTTCCATCCAGGTAA }\end{array}$ & Chang et al., 2009 \\
\hline AY957619 & TLR8 & 150 & $58^{\circ} \mathrm{C}$ & $\begin{array}{l}\text { forward } \\
\text { reverse }\end{array}$ & $\begin{array}{l}\text { TCCACATCCCAGACTTTCTACGA } \\
\text { GGTCCCAATCCCTTTCCTCTA }\end{array}$ & Menzies and Ingham, 2006 \\
\hline AM981307 & TLR9 & 175 & $60^{\circ} \mathrm{C}$ & $\begin{array}{l}\text { forward } \\
\text { reverse }\end{array}$ & $\begin{array}{l}\text { CCCTGGAGAAGCTGGACAT } \\
\text { GACAGGTCCACGAAGAGCAG }\end{array}$ & Chang et al., 2009 \\
\hline AM981308 & TLR10 & 149 & $58^{\circ} \mathrm{C}$ & $\begin{array}{l}\text { forward } \\
\text { reverse }\end{array}$ & $\begin{array}{l}\text { TGCCAAGACATCCATTCTGT } \\
\text { TGCCAAGACATCCATTCTGT }\end{array}$ & Chang et al., 2009 \\
\hline NM_001034034 & GAPDH & 134 & $58^{\circ} \mathrm{C}$ & $\begin{array}{l}\text { forward } \\
\text { reverse }\end{array}$ & $\begin{array}{l}\text { AGAAGGCTGGGGCTCACT } \\
\text { GGCATTGCTGACAATCTTGA }\end{array}$ & Herman et al., 2015 \\
\hline BC108088.1 & HDAC1 & 115 & $58^{\circ} \mathrm{C}$ & $\begin{array}{l}\text { forward } \\
\text { reverse }\end{array}$ & $\begin{array}{l}\text { CTGGGGACCTACGGGATATT } \\
\text { GACATGACCGGCTTGAAAAT }\end{array}$ & Herman et al., 2015 \\
\hline U39357 & ACTB & 168 & $58^{\circ} \mathrm{C}$ & $\begin{array}{l}\text { forward } \\
\text { reverse }\end{array}$ & $\begin{array}{l}\text { CTTCCTTCCTGGGCATGG } \\
\text { GGGCAGTGATCTCTTTCTGC }\end{array}$ & Herman et al., 2015 \\
\hline
\end{tabular}

TLR - Toll-like receptor, GAPDH - glyceraldehyde-3-phosphate dehydrogenase, HDAC1 - histone deacetylase 1, ACTB - beta-actin

\section{Results}

The mean concentration of circulating melatonin in the last hour of the experiment (at 21:00 during SD and 2:00 during LD) was higher $(P<$ $0.05)$ during the $\mathrm{SD}\left(270 \pm 15 \mathrm{pg} \cdot \mathrm{ml}^{-1}\right)$ compared with the LD period $\left(108 \pm 5 \mathrm{pg} \cdot \mathrm{ml}^{-1}\right)$ (Figure 1).

Transcripts for all TLR genes were found in the pineal gland. The level of gene expression for each particular TLR gene differed, however (Figure 2). TLR3 had the highest mRNA expression, followed by TLRs $1,2,5,7,9,8,4,10$ and 6 . Moreover, the expression of each TLR gene also varied and was influenced by the photoperiod and/or circulating melatonin. The gene characterized by the highest variation in the degree of expression was TLR10 (coefficient of variation, $42 \%$ ) during the $\mathrm{LD}$ period, but during the SD period, TLR6 expression varied most (coefficient of variation, $42 \%$ ) (Table 2 ). On the other hand, the gene showing the lowest variation in the degree of expression was TLRO (coefficient of varation, 12\%) during the LD period, but during the SD period the lowest variation was found for TLR2 (coefficient of variation, 14\%). Photoperiodic conditions did not influence TLR gene expression.

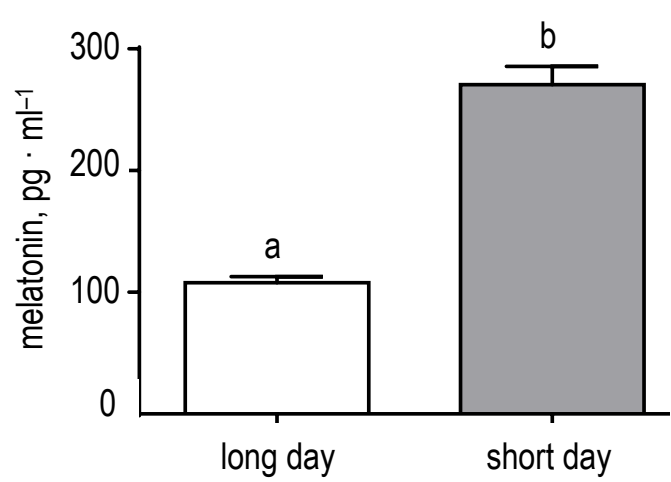

Figure 1. Mean ( \pm SEM) concentration of melatonin in blood plasma collected at the last hour of the experiment during long day (LD, 2:00, white bar) and short day (SD, 21:00, grey bar); $a, b$ - bars with different letters differ significantly at $P<0.05$ 


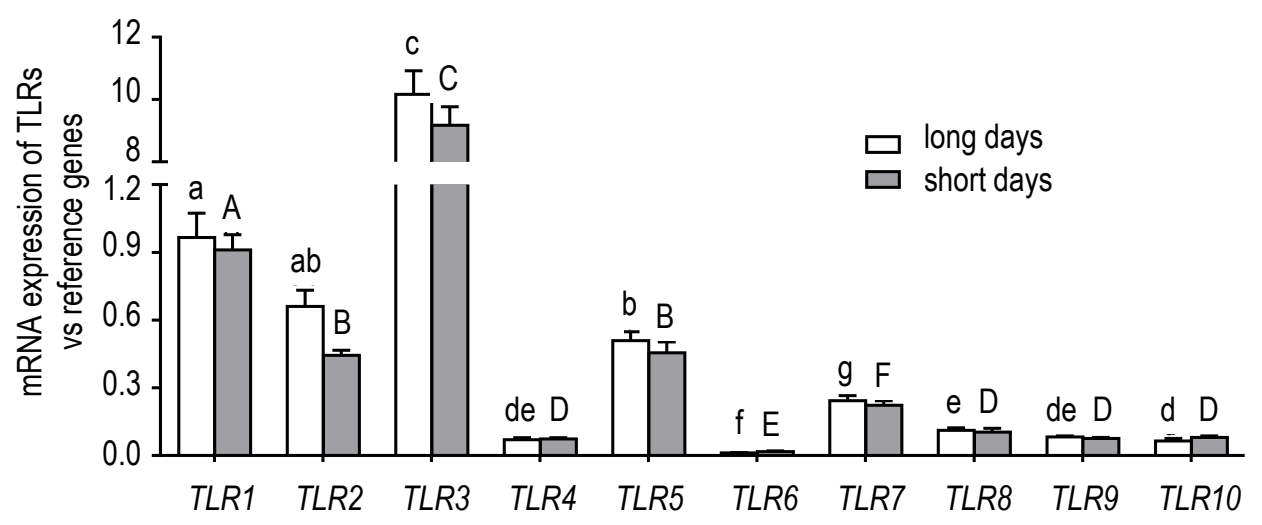

Figure 2. TLRs relative mRNA expression vs reference genes, during long day (LD, white bars) and short day (SD, grey bars) in the pineal gland of adult ewes. Data are presented as a mean \pm SEM. Bars with different letters (a-f for LD and A-F for SD) differ significantly at $P \leq 0.05$; TLR - Toll-like receptor

Table 2. The coefficient of variations (\%) for Toll-like receptors (TLRs) mRNA expression in the pineal gland collected during long and short days

\begin{tabular}{lllllllllll}
\hline Period & TLR1 & TLR2 & TLR3 & TLR4 & TLR5 & TLR6 & TLR7 & TLR8 & TLR9 & TLR10 \\
\hline Long days & 28 & 27 & 18 & 28 & 19 & 26 & 23 & 24 & 13 & 42 \\
Short days & 18 & 12 & 16 & 19 & 26 & 42 & 23 & 38 & 15 & 23 \\
\hline
\end{tabular}

${ }^{1}$ see Table 1

\section{Discussion}

The results of our study demonstrate that cells located in the pineal gland express mRNA encoding all 10 members of the TLR family. These receptors are able to recognize a wide range of exogenous and endogenous ligands. TLR2 recognizes a variety of microbial components such as lipoproteins/lipopeptides from various pathogens, peptidoglycan and lipoteichoic acid from gram-positive bacteria, lipoarabinomannan from mycobacteria, glycosylphosphatidylinositol anchors from Trypanosoma cruzi, a phenol-soluble modulin from Staphylococcus epidermis, zymosan from fungi, glycolipids from Treponema maltophilum and lipopolysaccharides (LPS) found in Leptospira interrogans and Porphyromonas gingivalis (Takeda et al., 2003; Takeda and Akira, 2005). TLR2 recognizes a wide range of microbial products through functional cooperation with several proteins that are either structurally related or unrelated. TLR2 forms heterophilic dimers with other TLRs such as TLR1 and TLR6, both of which are structurally related to TLR2. These receptors functionally associate with TLR2 and discriminate between diacyl or triacyl lipopeptides, respectively (Alexopoulou et al., 2002; Takeuchi et al., 2002). TLR 2 has also been shown to functionally collaborate with distinct types of receptors such as dectin-1, a lectin family receptor for the fungal cell wall component $\beta$-glucan (Takeda and Akira, 2005). TLR3, whose mRNA is predominantly expressed in the pineal gland, is involved in the detection of double-stranded RNA and viruses (Alexopoulou et al., 2001). TLR4 is an essential receptor for LPS recognition, but is also involved in the detection of taxol and some endogenous ligands such as heat shock proteins, extra domain A of fibronectins, oligosaccharides of hyaluronic acid, heparan sulphateand fibrinogen (Takeda and Akira, 2005). TLR5 recognizes flagellin, thus enabling detection of flagellated bacterial pathogens (Hayashi et al., 2001). TLR7 and TLR8 detect single-stranded RNA from viruses such as human immunodeficiency virus, vesicular stomatitis virus and influenza virus (Takeda and Akira, 2005). TLR9 has been shown to recognize various bacterial and viral components, including unmethylated CpG-DNA (Takeda and Akira, 2005). The ligand of TLR10 is still unidentified, however, it was demonstrated that TLR10 homodimerizes but also heterodimerizes with TLRs 1 and 2 (Hasan et al., 2005). The pineal gland is the circumventricular organ, which is characterized by fenestrated capillaries allowing for the movement of molecules in the paracellular space (Joly et al., 2007), therefore the activity of the pineal cells may be affected by a number of circulating factors. The fact that the expression of genes encoding all 10 members of the TLR family was demonstrated in our study suggests that their ligands may cross the fenestrated capillaries and influence the secretory activity of the pineal gland. This strongly supports the thesis about involvement of the pineal tissue in immune-endocrine interactions. It is worth mentioning that just recently we presented the profile of TLRs in the ovine 
choroid plexus (Skipor et al., 2015) in which the capillaries are fenestrated, but also covered by epithelial cells with tight junctions forming what is known as the blood-cerebrospinal fluid barrier (Skipor and Thiery, 2008). Transcripts for all ten TLRs except $T L R 8$ were present in the choroid plexus, but only TLR3, TLR7, TLR9 and TLR10 presented relatively invariant expression levels (coefficient of variation, $7 \%$ to $17 \%$ ). There was high variation in the degree of expression of the TLR5 and TLR1 genes (61\% and $46 \%$, respectively) as well as moderate variation in the expression of the TLR4 (34\%), TLR2 (27\%) and TLR6 (26\%) genes (Skipor et al., 2015). Our study shows that the profile of TLR mRNA expression in the pineal gland was generally independent of the photoperiodic conditions and/or the circulating level of melatonin. However, it was found that only TLR3, $T L R 7$ and TLR 9 were characterized by similar interindividual variability of mRNA expression in the pineal gland, regardless of different photoperiodic conditions. Our study does not allow drawing conclusions about which factors influence the interindividual variation in the mRNAs encoding other TLRs in the SD and LD photoperiods. Although it was suggested that the expression of TLRs may be modulated by circulating glucocorticoids (Shuto et al., 2002), no correlation between cortisol concentration and mRNA expression of any of the examined TLRs was found in our previous study performed on sheep (Skipor et al., 2015).

Based on our results, it is not possible to infer about the type of pineal cells expressing TLRs, however, their existence may have a profound influence on the secretory activity of the whole gland. It could be assumed that these receptors are mainly expressed on the glial cells. It was previously described that rat pineal astrocytes and microglia react to bacterial endotoxins such as LPS and lipotheic acid thanks to the existence of membrane receptors for LPS, such as TLR4 and cluster of differentiation 14 (CD14) (da Silveira Cruz-Machado et al., 2010). However, more recent studies showed the expression of TLR4 in isolated pinealocytes themselves and suggested that LPS may reduce melatonin secretion by both acting directly on pinealocytes and indirectly through activated glial cells (da Silveira Cruz-Machado et al., 2012). Our results suggest that the spectrum of molecules affecting the function of pineal cells could be much wider. Nevertheless, studies analysing the possible influence of diverse ligands of other TLRs on the secretory activity of the pineal gland have yet to be carried out. The dominant expression of mRNA for $T L R 3$ in the pineal gland deserves special attention as this suggests that pineal tissue is particularly sensitive to viral-derived PAMPs. Notwithstanding, the role of TLR3 in the pineal gland may be more complex. Recent studies carried out on mice (Pan et al., 2014) showed that astrocytic TLR3 signaling plays an important role in suppression of the post-ischaemic inflammatory response and thereby protects against ischaemic damage. Therefore, the expression of TLR3 in the pineal gland may be involved in the protection of this tissue against strong inflammatory stimulation. Worth mentioning is that the involvement of TLRs in the modulation of melatonin secretion may result from the induction of inflammatory mediator synthesis in the cells of the pineal gland. It has been reported that ligation of TLR2, TLR3 and TLR4 by these receptors' agonists resulted in activation of nuclear factor kappa-lightchain-enhancer of activated B cells (NF-kb), c-Jun $\mathrm{N}$-terminal kinases (JNK) and p38 mitogen-activated protein kinases (MAP), leading to the expression of pro-inflammatory cytokines such as TNF- $\alpha$, IL-1 and IL-6. TLR3 and TLR4 are known to induce the synthesis of type I interferon (IFN- $\alpha$ and IFN- $\beta$ ) in response to viral and bacterial antigens (Schaefer et al., 2004). These locally synthesized inflammatory mediators may, in turn, affect melatonin secretion by acting directly on pinealocytes or indirectly on pineal glial cells. It has been suggested that the effect of cytokines such as IFN- $\gamma$ and IL- $1 \beta$ on pineal melatonin synthesis may be mediated by microglia, whereas TNF- $\alpha$ may exert its biological effects directly on pinealocytes (Tsai et al., 2001).

Although our findings indicate that the mRNA of all 10 members of the TLR family is expressed in the pineal gland of ewes, it should be stressed that further studies are necessary to examine the protein profiles of the TLRs. Mishra et al. (2006) demonstrated that not all TLRs for which mRNA was found were expressed as proteins. They suggested that the expression of some TLRs may be regulated at the posttranscriptional level. However, a more recent study suggests that the variability found in TLR protein expression may result from the use of antibodies lacking high specificity (Mallard, 2012).

\section{Conclusions}

Our study shows that the cells of the sheep pineal gland express transcript for all ten members of the Toll-like receptors family, which suggests that the functioning of this gland may be affected by a number of pathogen-associated molecular patterns recognized by these receptors. 


\section{Acknowledgements}

This work was supported by Polish National Science Centre (NCN), Grant No. 2011/03/D/ NZ9/04021.

\section{References}

Alexopoulou L., Czopik Holt A., Medzhitov R., Flavell R.A., 2001. Recognition of double-stranded RNA and activation of NF-KB by Toll-like receptor 3. Nature 413, 732-738

Alexopoulou L., Thomas V., Schnare M., Lobet Y., Anguita J., Schoen R.T., Medzhitov R., Fikrig E., Flavell R.A., 2002. Hyporesponsiveness to vaccination with Borrelia burgdorferi OspA in humans and in TLR1- and TLR2-deficient mice. Nat. Med. 8, 878-884

Arendt J., 1998. Melatonin and the pineal gland: influence on mammalian seasonal and circadian physiology. Rev. Reprod. 3 , 13-22

Carrillo-Vico A., Lardone P.J., Alvarez-Sánchez N., Rodríguez-Rodríguez A., Guerrero J.M., 2013. Melatonin: buffering the immune system. Int. J. Mol. Sci. 14, 8638-8683

Chang J.S., Russell G.C., Jann O., Glass E.J., Werling D., Haig D.M., 2009. Molecular cloning and characterization of Toll-like receptors 1-10 in sheep. Vet. Immunol. Immunopathol. 127, 94-105

da Silveira Cruz-Machado S., Carvalho-Sousa C.E., Tamura E.K. Pinato L., Cecon E., Fernandes P.A., de Avellar M.C., Ferreira Z.S., Markus R.P., 2010. TLR4 and CD14 receptors expressed in rat pineal gland trigger NFKB pathway. J. Pineal Res. 49, 183-192

da Silveira Cruz-Machado S., Pinato L., Tamura E.K., Carvalho-Sousa C.E., Markus R.P., 2012. Glia-pinealocyte network: the paracrine modulation of melatonin synthesis by tumor necrosis factor (TNF). PLoS One 7, e40142, doi: 10.1371/journal. pone.0040142

Fabris N., 1994. Neuroendocrine regulation of immunity. In: G.J.M. Maestroni, A. Conti, R.J. Reiter (Editors). Advances in Pineal Research, Vol. 7. John Libbey EUROTEXT Ltd. Montrouge (France), pp. 41-56

Fraser S., Cowen P., Franklin M., Franey C., Arendt J., 1983. Direct radioimmunoassay for melatonin in plasma. Clin. Chem. 29, 396-397

Gupta B.B., Spessert R., Vollrath L., 2005. Molecular components and mechanism of adrenergic signal transduction in mammalian pineal gland: regulation of melatonin synthesis. Indian J. Exp. Biol. 43, 115-149

Hasan U., Chaffois C., Gaillard C. et al., 2005. Human TLR10 is a functional receptor, expressed by B cells and plasmacytoid dendritic cells, which activates gene transcription through MyD88. J. Immunol. 174, 2942-2950

Hayashi F., Smith K.D., Ozinsky A., Hawn T.R., Yi E.C., Goodlett D.R., Eng J.K., Akira S., Underhill D.M., Aderem A., 2001. The innate immune response to bacterial flagellin is mediated by Toll-like receptor 5. Nature 410, 1099-1103

Herman A.P., Bochenek J., Skipor J., Król K., Krawczyńska A., Antushevich H., Pawlina B., Marciniak E., Tomaszewska-Zaremba D., 2015. Interleukin-1ß modulates melatonin secretion in ovine pineal gland: ex vivo study. BioMed Res. Int. 2015:526464, doi: 10.1155/2015/526464

Herman A.P., Herman A., Haziak K., Tomaszewska-Zaremba D., 2013. Immune stress up regulates TLR4 and Tollip gene expression in the hypothalamus of ewes. J. Anim. Feed Sci. 22, 13-18
IZ PIB-INRA, 2009. Standards for Ruminant Feeding (in Polish). National Research Institute of Animal Production, Kraków (Poland)

Joly J.S., Osório J., Alunni A., Auger H., Kano S., Rétaux S., 2007. Windows of the brain: Towards a developmental biology of circumventricular and other neurohemal organs. Semin. Cell Dev. Biol. 18, 512-524

Mallard C., 2012. Innate immune regulation by Toll-like receptors in the brain. ISRN Neurol. 2012:701950, doi: 10.5402/2012/701950

Markowska M., Bialecka B., Ciechanowska M., Koter Z., Laskowska H., Karkucinska-Wieckowska A., Skwarlo-Sonta K., 2000. Effect of immunization on nocturnal NAT activity in chicken pineal gland. Neuroendocrinol. Lett. 21, 367-373

Markus R.P., Ferreira Z.S., 2011. The immune-pineal axis: the role of pineal and extra-pineal melatonin in modulating inflammation. Adv. Neuroimmune Biol. 1, 95-104

Menzies M., Ingham A., 2006. Identification and expression of Toll-like receptors 1-10 in selected bovine and ovine tissues. Vet. Immunol. Immunopathol. 109, 23-30

Mishra B.B., Mishra M.K., Teale J.M., 2006. Expression and distribution of Toll like receptors in the brain during murine neurocysticercosis. J. Neuroimmunol. 181, 46-56

Moore R.Y., 1997. Circadian rhythms: basic neurobiology and clinical applications. Annu. Rev. Med. 48, 253-266

Mucha S., Zylinska K., Zerek-Meten G., Swietoslawski J., Stepien H., 1994. Effect of interleukin-1 on in vivo melatonin secretion by the pineal gland in rats. In: G.J.M. Maestroni, A. Conti R.J., Reiter (Editors). Advances in Pineal Research, Vol. 7. John Libbey EUROTEXT Ltd. Montrouge (France), pp. 177-181

Pan L.N., Zhu W., Li Y., Xu X.L., Guo L.J., Lu Q., Wang J., 2014. Astrocytic Toll-like receptor 3 is associated with ischemic preconditioning-induced protection against brain ischemia in rodents. PLoS. One 9, e99526, doi: 10.1371/journal.pone.0099526

Radogna M., Diederich M., Ghibelli L., 2010. Melatonin: A pleiotropic molecule regulating inflammation. Biochem. Pharmacol. 80 , 1844-1852

Rasmussen R., 2001. Quantification on the LightCycler. In: S. Meuer, C. Wittwer, K.-I. Nakagawara (Editors). Rapid Cycle RealTime PCR. Springer-Verlag. Berlin (Germany), pp. 21-34

Russel A., 1991. Body condition scoring of sheep. In: E. Boden (Editor). Sheep and Goat Practice. Bailliére Tindall. Philadelphia (USA), pp. 3

Schaefer T.M., Desouza K., Fahey J.V., Beagley K.W., Wira C.R., 2004. Toll-like receptor (TLR) expression and TLR-mediated cytokine/chemokine production by human uterine epithelial cells. Immunology 112, 428-436

Schomerus C., Korf H.W., 2005. Mechanisms regulating melatonin synthesis in the mammalian pineal organ. Ann. NY Acad. Sci. 1057, 372-383

Shuto T., Imasato A., Jono H. et al., 2002. Glucocorticoids synergistically enhance nontypeable Haemophilus influenza-induced Toll-like receptor 2 expression via a negative cross-talk with p38 MAP kinase. J. Biol. Chem. 277, 17263-17270

Skinner D.C., Malpaux B., 1999. High melatonin concentrations in third ventricular cerebrospinal fluid are not due to Galen vein blood recirculating through the choroid plexus. Endocrinology 140, 4399-4405

Skipor J., Szczepkowska A., Kowalewska M., Herman A.P., Lisiewski P., 2015. Profile of Toll-like receptor mRNA expression in the choroid plexus in adult ewes. Acta Vet. Hung. 63, 69-78

Skipor J., Thiery J.-C., 2008. The choroid plexus-cerebrospinal fluid system: Undervaluated pathway of neuroendocrine signaling into the brain. Acta Neurobiol. Exp. 68, 414-428 
Skwarlo-Sonta K., Majewski P., Markowska M., Oblap R., Olszanska B., 2003. Bidirectional communication between the pineal gland and the immune system. Can. J. Physiol. Pharmacol. 81, 342-349

Takeda K., Akira S., 2005. Toll-like receptors in innate immunity. Int. Immunol. 17, 1-14

Takeda K., Kaisho T., Akira S., 2003. Toll-like receptors. Annu. Rev. Immunol. 21, 335-376

Takeuchi O., Sato S., Horiuchi T., Hoshino K., Takeda K., Dong Z., Modlin R.L., Akira S., 2002. Cutting edge: role of Toll-like receptor 1 in mediating immune response to microbial lipoproteins. J. Immunol. 169, 10-14
Tsai S.-Y., O'Brien T.E., McNulty J.A., 2001. Microglia play a role in mediating the effects of cytokines on the structure and function of the rat pineal gland. Cell Tissue Res. 303, 423-431

Vitkovic L., Bockaert J., Jacque C., 2000. "Inflammatory" cytokines: neuromodulators in normal brain? J. Neurochem. 74, 457-471

Voisin P., Van Camp G., Pontoire C., Collin J.P., 1993. Prostaglandins stimulate serotonin acetylation in chick pineal cells: involvement of cyclic AMP-dependent and calcium/calmodulin-dependent mechanisms. J. Neurochem. 60, 666-670

Zawilska J.B., Woldan-Tambor A., Nowak J.Z., 1997. Histamine-stimulated cyclic AMP formation in the chick pineal gland: Role of protein kinase C. Biochem. Pharmacol. 54, 501-507 